\title{
Factors Related to the Level of Perceived Quality of Academic and Administrative Services by Users: Case of the National University of the Altiplano, Puno, Peru
}

\author{
Juan Inquilla-Mamani $\odot$, Fermin F. Chaiña-Chura $(1)$ \\ National University of the Altiplano, Puno, Perú \\ Email: inquilla@hotmail.com, fchaina1@hotmail.com
}

How to cite this paper: Inquilla-Mamani, J. and Chaiña-Chura, F.F. (2019) Factors Related to the Level of Perceived Quality of Academic and Administrative Services by Users: Case of the National University of the Altiplano, Puno, Peru. Open Access Library Journal, 6: e5467.

https://doi.org/10.4236/oalib.1105467

Received: May 13, 2019

Accepted: July 2, 2019

Published: July 5, 2019

Copyright $\odot 2019$ by author(s) and Open Access Library Inc.

This work is licensed under the Creative Commons Attribution International License (CC BY 4.0).

http://creativecommons.org/licenses/by/4.0/ (c) (i) Open Access

\begin{abstract}
The purpose of this research is to determine the conditioning factors of quality of academic and administrative services perceived by users of the National University of the Altiplano (UNA-Puno). In the methodological part, the different statistics are presented as Kendall's Taub test, Factorial analysis of the components, Factors extraction, Varimax rotation, $\mathrm{T}$ test and correlation estimates and multiple linear regression. The study is of transversal design the study sample is made up of students, teachers and administrative staff of the UNA-P, of a simple random type. The measurement instrument applied was the Servqual Questionnaire. For the processing and statistical analysis of the information, the SPSS v. 22 program. The results obtained through the reliability analysis of the Servqual model show us a Cronbach alpha of 0.709, which means that both the instrument and its attributes are reliable and consistent to measure the quality of the service. Considered in the model determine in $67.11 \%$ the levels of service quality, $R^{2}$ is 0.746 and value of $F=0.000$. Therefore, the factors identified in the analysis directly and significantly affect the level of perceived quality.
\end{abstract}

\section{Subject Areas}

Education, Sociology

\section{Keywords}

Evaluation of Quality, Quality of Service, Higher Education, University and Servqual Model 


\section{Introduction}

The present research project evidences the validation of the Servqual model for the evaluation of the perceived quality of the users on the academic and administrative services of the National University of the Altiplano (UNA)-Puno. Likewise, the components and characteristics as conditioning factors of the quality of the services in higher education and propose the strategic dimensions that should be prioritized and implemented to improve the quality of the academic and administrative services are the purposes of the present investigation.

In Peru, the private offer of higher education has grown considerably in recent years, however, it is not known whether the increase in quality levels in university higher education has been in the same magnitude. Especially in the universities of the regions of the interior of the country, where the student population comes mainly from popular and rural sectors, in addition, it is known that these young people are of scarce resources and therefore have fewer opportunities to access a quality education at the secondary level, and they arrive at the university with many learning limitations. In this context, the university has a shared social responsibility, in terms of the quality of academic service it offers in the process of training professionals. Let us take into account an area of training in the university (education), to explain how the circle of low quality is reproduced: if we provide low-quality academic services, then we will have poorly prepared professionals (teachers), so we will have students of education basic regular with learning limitations, therefore, these will reach the university with learning limitations and continue in the cycle we will have as product graduates with low level of professional skills, then if so, our graduates will have many limitations in accessing a job worthy, therefore, will remain with low levels of income.

Nowadays, the academic and administrative quality that universities should tend is one of the fundamental bases of academic and public discourse, in addition, political discourses are centered on it, but fundamentally, quality is the input of the development of public institutions and private providers of goods and services preferably in the educational field. In the country, the concern of academic quality in education, mainly in university higher education, has become a central issue; all this is evidenced in the new University Law $\mathrm{N}^{\circ} 30220$, it is for this reason that tools are needed that allow educational entities of higher education to measure the degree of satisfaction of their users. One of these tools is the quality management systems (Servqual) that are used to ensure that the goods and services produced to meet the expectations of their users and that the processes used to develop them meet the objectives set and are the more efficient. The National University of the Altiplano does not escape from this reality, in the macro region of the south of the country it is a fundamental pillar for the development of the country, no one can doubt now that the future of the nation lies in the education and training of professionals prepared with adequate skills to ensure their progress and that of the country.

As an introduction to theoretical reflection one has; from the organizational 
perspective introduced in education, [1] defines quality as the satisfaction of the needs and expectations of users. Under this same perspective, in the definition cited by the International Standard Organization (ISO) we find that [2] indicates that quality is also identified with the satisfaction of needs, because "quality is a set of properties or characteristics of a product or service that gives it the ability to satisfy explicit or implicit needs" (p. 55). In this sense, [3] affirms that when providing a service, the expectations of customers/users about the educational service offer must be met. In this case, it is the fulfillment of the processes implicit in education. With this, quality means the satisfaction of the interested parties, comprising both the authorities of the university and the students that comprise it.

\section{Literature Review}

\subsection{Quality in Higher Education}

Currently there is a growing interest in the issue of educational quality in the university environment as a result of the social, political and economic demands that require the active participation of the university in the development of the countries, which is why it is necessary to identify which are its determining factors and how they affect the functioning of the university [4]. There are several factors by which a Latin American university has a low level of teaching quality. Many of the Latin American universities are state-run, state governments are oblivious to quality control, and when they claim to demand educational quality, they respond by appealing to the principle of University Autonomy. Certain works have focused on the assessment of the overall experience of students at the university in relation to the set of services offered not only at the teaching level but also include study support services and general services such as those related to with sports, cultural and coexistence development.

It is widely known that higher education has a direct impact on the country's competitiveness through its effect on the productivity of its workforce. The presence of competent professionals is, without a doubt, one of the factors analyzed by investors when making their decisions. On the other hand, the results of higher education also have a significant "feedback" in basic education, both for the better preparation of teachers and the presence of more enlightened parents who will be demanding with the education of their children. The relationship between quality education and investment in science and technology, and social and economic well-being is directly related. Research supports that the quality of education has a strong impact on the economic growth of countries, and that access to higher education is an important vehicle for social mobility [5].

On the other hand, [6] affirms that the concern today is not how many students receive the educational institutions and in what proportion, but rather who learn, what they learn and in what conditions they learn. Therefore, the great challenge of education for the 21st century is the search for quality [7] [8] directly related to student satisfaction, which must be provided Complete educa- 
tion through innovative teaching methodology, through the effective use of resources and transmitting conceptual, procedural and attitudinal content, which allows it to develop with social being, both professionally and personally. The search and promotion of quality in education has to be constituted as a reflective process, systematized and agreed on by all the members of the university community with the objective of carrying out the evaluation of the situation in which the different processes take place. Educational this will lead to the discovery of the potentialities of the institution and the elements that constitute it will help to identify the weaknesses and will promote the development of innovative proposals that execute the desired change and achieve a continuous and constant development of both the institution and its members.

The UNESCO World Declaration on Higher Education in the 21st Century expands this definition in terms of its evaluation, involving more categories of analysis. According to UNESCO: "Quality is the adaptation of the Being and Work of Higher Education to its Duty." That is to say, the Mission (Duty to Be), as well as the plans and projects that derive from it, are evaluated in terms of their relevance; the operation (What to do) is evaluated in terms of efficiency; and the achievements and results (Being) are evaluated in terms of their effectiveness. There are important studies [9] that hold that the 21st century has begun with an increase in the number of students in higher education. According to UNESCO, enrollment has progressively increased in the world. This large expansion can be attributed, at least, to two reasons: an increase in the social demand for higher education and a growing economic need to hire personnel graduated in higher education.

However, it would be incomplete, if you do not take into account the process by which the concept of education was developed, in the literature you can find different perspectives on the quality of higher education, however, the concept of education was consolidated in the theory of human capital, highlighting the investment in people as a fundamental factor for the growth and well-being of the countries. Authors such as [10] [11] [12], argue that human capital is consolidated as a segment in economic analysis, which has proven to be a contributor to economic growth, taking into account that Education gives the worker the possibility of accessing higher-paid jobs and increasing their quality of life. But, the theoretical referents that have given greater relevance to the education of people for individual and social development, we find from [13], who refers to the importance of skill and dexterity to perform the work, until the last studies that are carried out at present, where all converge in considering the investment in education as a fundamental component to develop the abilities and capacities of the individuals, and contribute to the economic growth of a country.

These issues have been worked by different economists, making up what is now called education economics. [10] [11] [12] were concerned about studying education, medical expenses, on-the-job training and finding information for employment as an investment, which increases the long-term However, it should 
be noted that the theory of "human capital" has its starting point in the conference given by Theodore W. Schultz in 1960 in the American Economic Association, where the term was first coined as a synonym of education and training [14], said "by investing in themselves, human beings increase the field of their possibilities, it is a way by which men can increase their well-being." According to the author, any worker, inserting itself in the productive system, not only contributes its physical strength and its natural ability, but also, comes with it a baggage of knowledge acquired through education.

\subsection{Management of Educational Quality in Higher Education}

For many authors, educational quality is understood as that process that helps develop the potential of the student through the satisfaction of their needs for intellectual and personal growth. To improve and improve the meaning of educational quality arises within the educational context, the Total Quality Management system that emphasizes customer satisfaction and their perception of quality. This system has its origins in the North American model MalcomBraldrige, the Deming model and the works developed by (Cornesky, Municio, Apodaca and Lobato, 1990, 1994 and 1997 cited in [15]. In the educational field, quality and the criteria for measuring it have also undergone transformations. Thus, in the 1990s, policies and evaluation of University Quality were promoted, where not only does the institution make an internal assessment with its own criteria for quality evaluation, but it also goes to the evaluation of external experts based in international standards as a consensual reference mode to determine excellence [15] [16]. Currently, an example that we have, is the model of the Accreditation Criteria for different university careers, which seeks that the career identifies and meets the needs of students, in order to form a profile of the graduate. To do this, it is based on criteria that allow relevant improvements to be made in the evaluated careers. These criteria refer to the educational objectives, the skills and attitudes to be developed in the students, the teaching staff, the infrastructure facilities and study materials and the financial support of the university educational institution.

Quality management is an articulated set of elements of the humanist school, the systemic perspective and the organizational culture, with which motivational psychological aspects and variables of the organizational climate are related. It can be said that total quality management in education is understood as a management process or practice that uses the total quality approach as a principle and strategy, whose management philosophy implies a way of understanding the institution, its strategies, aims and objectives, as well as the people related to it and its processes, directing its goals towards the satisfaction of the client's requirements and expectations [16] [17], cited by [18], under a system of values, principles, norms and procedures, product of an organizational culture

Therefore, the management of total quality seeks to create new needs and possibilities for academic training, giving greater importance to teaching processes 
where the student is involved in their own learning [19]. Accordingly, the educational quality would be measured in terms of the adequacy of the service provided with respect to pre-established characteristics, which should be known by the educational institution in order to try to approach the needs of the clients [20]. Although, traditionally they have been considered as customers of an organization to those final recipients of the products or services offered by said organization, nowadays, the notion of client incorporates the workers and managers of the organization or institution as component members of the same and they are called internal clients, while the consumers are called external clients [17]. From this perspective, in the education system, both university students and parents would be considered in the category of external clients, because they are the ones who receive the service and pay for it respectively. However, students could also be considered as internal clients insofar as they join and become part of the educational institution.

In the same perspective, for [21], the satisfaction of customers in education makes direct reference to the satisfaction of students, since they are the immediate recipients to whom the educational product is offered, understood as educational product, the education given, the degrees, the graduates, etc., which are not tangible goods, but knowledge services, as indicated [22]. Likewise, the satisfaction of the students is oriented towards the attention of their own educational needs in their diverse manifestations, and to the achievement of the expectations that the educational institution proposes in this area. Therefore, the author considers as one of the identifiers of the quality of the educational product, it is the satisfaction of the students themselves.

According to [9] there are two types of quality assurance: internal and external. The internal quality assurance ensures that an institution or program has policies and mechanisms in place to ensure that it meets its own objectives and standards. The external guarantee of quality is supervised by an organization outside the institution. The external organization evaluates the operation of the institution or its programs in order to determine whether or not it meets the agreed or predetermined standards, as mentioned above. Quality assurance involves a series of practices, among which we can distinguish three mechanisms: quality audit, quality assessment and accreditation.

\subsection{Quality Models}

[4] indicates that currently, two major trends in quality management coexist, which provide two different models. Each model is based on ensuring that the necessary processes are carried out so that the products and services satisfy the customers. The main international awards correspond to the Deming Prize in Japan, the Malcolm Baldrige National Quality Award (PNCMB) in the USA and the European Quality Award. Other approaches are based on the purpose of the awards themselves, which "seek recognition of exemplary companies in quality management [23]. the most widespread models of total quality management are 
the Deming Model, created in 1951, the Malcolm Baldrige Model, in 1987, and the European Quality Management Model, EFQM, created in 1992. The author summarizes the quality models of the Following way:

The Deming Model

It was developed in Japan in 1951 by the Japanese Union of Scientists and Engineers (JUSE) and includes the practical application of Japanese theories of total control of quality or quality control throughout the company. The main objective of the evaluation is to verify that through the implementation of quality control throughout the company have obtained good results. The basic approach is customer satisfaction and public welfare. Among the biggest contributions made by Deming are the already known 14 points of Deming, as well as the Shewart cycle, also known as PDCA: plan, do, verify and act.

The Malcolm Baldrige Model

It constitutes a basis for the realization of organizational self-evaluations and to provide feedback to its users. Additionally, it has three important roles to strengthen the competitiveness of organizations: helping to improve their management practices, capabilities and results; facilitate communication and exchange of information on best practices among organizations of all types and serve as a working tool to understand and manage performance, planning and learning opportunities. Its objectives are: 1) to provide permanently greater value to clients and interest groups, contributing to the sustainability of the organization; 2) improving the effectiveness and capabilities of the entire organization; 3) learning, both organizational and personal.

\section{The EFQM Model}

It is a framework of non-compliant work that conceives and develops the concepts of total quality and is oriented towards excellence. The EFQM Excellence Model is based on the following premise: "Excellent results in the overall performance of an organization, its clients, people and the society in which it operates, are achieved through a leadership that directs and promotes the policy and strategy, which will become a reality through the people of the organization, alliances and resources and processes." EFQM considers quality management as satisfying the needs and expectations of its customers, its staff, and the other entities involved. It consists of a tool for quality management whose objective is to guide the organization towards the client. One of the results of this model will be the sensitization of the management team and the rest of the personnel of the organization to fulfill the objective of improving the quality of their products or services.

\subsection{The Theory of Factors in User Satisfaction}

The studies carried out by [24] [25] argue that the satisfaction of the user/client is linked to each specific transaction, unlike the attitude towards a product or service that is general and can exist without there being a personal experience of purchase and of concrete consumption. Perceived quality of service is similar to 
the attitude towards service and is not linked to each specific transaction as customer satisfaction, but is a global or overall assessment of the service [26]. The Theory of two Factors states that the factors that generate dissatisfaction in workers are of a totally different nature from the factors that produce satisfaction. The theory starts from the fact that man has a double system of needs: the need to avoid pain or unpleasant situations and the need to grow emotionally and intellectually. Because they are qualitatively different, each type of need, in the world of work, requires different incentives. That is why we can talk about two types of factors that intervene in motivation at work. Herzberg, stresses that only the hygiene factors were taken into account in the motivation of employees, work is an unpleasant situation and to get workers to perform better and more efficiently, can be rewarded and incentivize salary, i.e., The person is encouraged to make a change in the work. According to Herzberg's research, when hygienic factors are optimal, it avoids employee dissatisfaction, and when hygienic factors are bad, they cause dissatisfaction [27].

For Herzberg, hygienic factors or extrinsic factors are related to dissatisfaction, because they are located in the environment that surrounds people and cover the conditions in which they perform their work. As these conditions are managed and decided by the company, the hygienic factors are beyond the control of the people. The main hygienic factors are: the salary, the social benefits, the type of management or supervision that people receive from their superiors, the physical and environmental working conditions, the policies and guidelines of the company, the climate of relations between the company and the people who work there, the internal regulations, status and prestige, and personal safety, etc.

Motivational factors or intrinsic factors are related to the satisfaction in the position and the nature of the tasks that the individual performs. For this reason, the motivational factors are under the control of the individual, since they are related to what he does and performs. Motivational factors involve feelings related to personal growth and development, professional recognition, self-fulfillment needs, greater responsibility and depend on the tasks that the individual performs in their work.

According to [27], the motivating factors attributed to the context and content of the job. The first refers to hygiene factors, because they act by eliminating or preventing problems or requirements. In this context, hygiene factors include aspects such as supervision, the physical conditions of work, interpersonal relationships, remunerations, benefits, safety at work, and the institutional policies and administrative practices of the company or organization. When these factors are not present, it generates dissatisfaction. However, when they are present, they do not always generate employee motivation, but only contribute to diminishing or eliminating dissatisfaction. The second set of factors refers to the content of the job, and these have to do with aspects such as personal fulfillment, recognition of performance, opportunities for professional advancement and personal growth, among other elements. Herzberg argues that if these factors are 
present in the work contribute to the level of motivation of the employee, thus stimulating a much higher performance and therefore provides a quality service.

[28] Noted that "quality is not what you put into a service, it's what the user gets from him and what he's willing to pay for." It can be understood that users do not buy a service for what the entity or "company" offers, they do it to feel good or to solve their problems. It also notes that "users buy the benefits expectations that they think the organization will offer them"(p. 21.). [29] argues that the user, in the case of services, not only assesses the quality with respect to the service produced or the final product, but also the form in which it is supplied or delivered. The quality of services includes these two classifications, since they are part of what consumers expect and receive from a company (expectations and perceptions). On the other hand, [30] defines the quality of the service as the extent of the discrepancy or difference that exists between the expectations or desires of the users and their perceptions.

\subsection{Evaluation of the Quality of Service}

It is important to highlight that the quality of services is an abstract and complex concept, the object of innumerable studies and investigations. The evaluation of quality in services is closely related to the expectation and satisfaction of the user, constituting the latter in the emotional and personal reaction to the service by the user. The services have their own characteristics such as intangibility, simultaneity and heterogeneity, characteristics that differentiate them from the products; thus, the methods of quality control that are applied to the production of goods cannot be applied to obtain the quality of the services [26], define the quality of service perceived as the global judgment of the client about the excellence or superiority of the service, which results from the comparison between the expectations of the consumers (what they believe that the service companies must offer) and your perceptions about the results of the service offered. According to [31], the SERVQUAL model is a powerful in-depth commercial research technique that allows a quality level measurement of any type of service company, allowing to know what expectations customers have and how they appreciate them. The service, also globally diagnoses the service process under study (see Figure 1).

These "gaps" are described as follows:

Gap 1: indicates the discrepancy between the expectations of customers about a specific service and the perceptions or beliefs that managers form about what the consumer expects from that service.

Gap 2: measures the difference between managers' perceptions and specifications or quality standards.

Gap 3: calculates the difference between the specifications or standards of service quality and service provision.

Gap 4: measures the discrepancy between the provision of the service and external communication. All the mentioned deficiencies mean that the service 


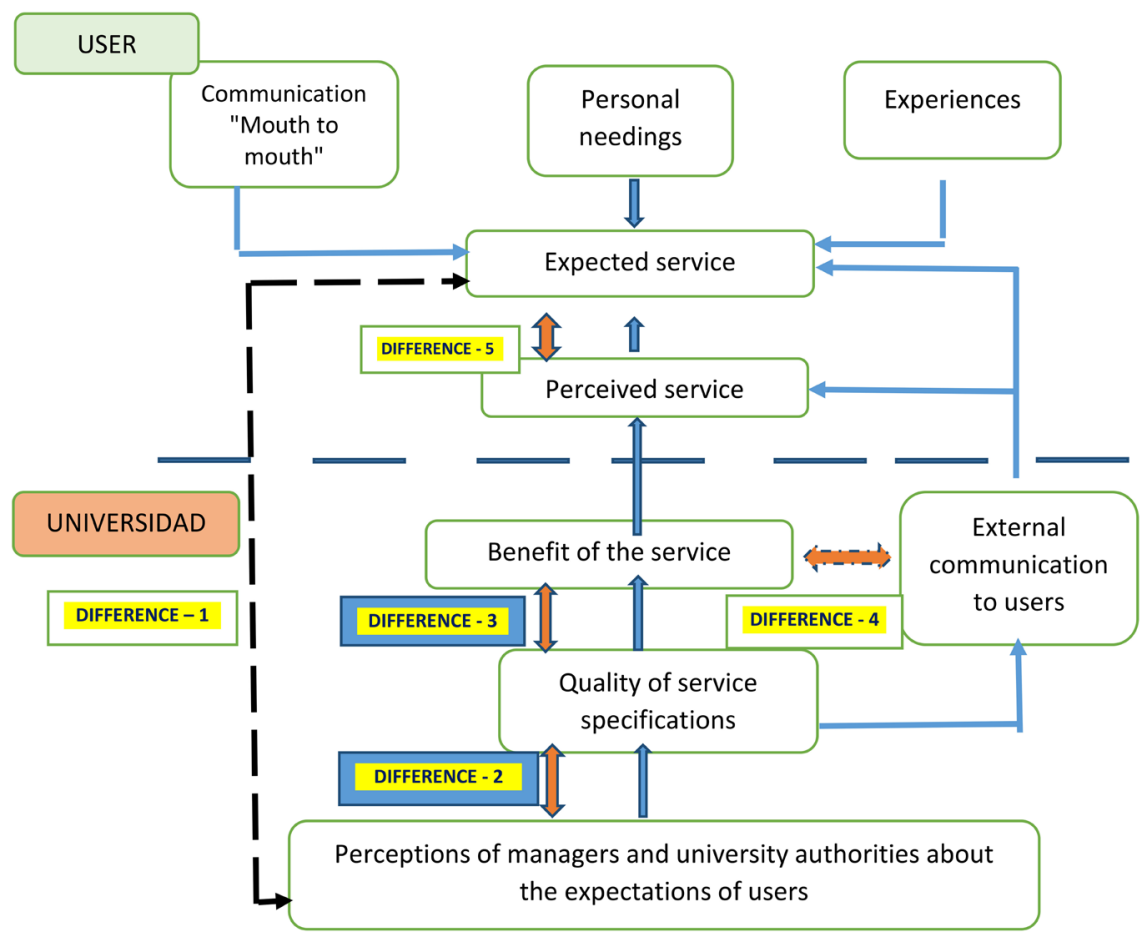

Figure 1. Conceptualization of the quality of services. Source: own elaboration based on Zeithaml (1992).

provided by the organization does not cover the expectations that the clients had placed in it, producing the Gap 5: which measures the difference between the expected service and the perceived service, determining through this magnitude the level of quality achieved. The way to reduce this difference is by controlling and decreasing all others.

Gap5 = f(Gap 1, Gap 2, Gap 3, Gap 4).

In the perspective of quality studies with the Servqual model, we have [32], the author cites some key aspects of quality in educational centers: First, quality is to ensure that our users, both internal (teaching staff, not teachers) and external (parents, students, society) are satisfied with everything that the Educational Center offers them. Second quality is the correct use of available resources, both own and foreign, both human and material. Third, quality is to develop in the educational center a continuous improvement, contrasted and valued by all and fourth, quality implies everyone and everything.

In the same line [33] considers that a service is not a physical element in its entirety, but is the result of the activities generated by the provider to satisfy the user. This implies that the services have three typical characteristics that explain the complexity of their study: Intangibility: a service is not an object that can be owned or palpated, it is rather a benefit that the user acquires. Heterogeneity: the result of the service depends on who carries it out and the circumstances under which it is generated; your perception depends on the person who hires you. Inseparability: this concept implies that the production and consumption of the 
service occur simultaneously, so the user is involved in it. Customer satisfaction is achieved when the expectations generated before receiving a service are exceeded by the value it receives once it has been received. As the value perceived by the customer exceeds their expectations, the customer will feel more satisfied.

\subsection{Theory of the SERVQUAL Model}

The original SERVQUAL scale was revised a few years later by its authors, through an empirical trial through a survey. Using the test data, the means and standard deviations of the SERVQUAL items were calculated, as well as the reliability coefficients (alpha coefficients), by means of the scores obtained as a result of the difference between perceptions and expectations for the five proposed dimensions, i.e., tangibility, reliability, responsiveness, security and empathy (see Figure 2) [34]. These changes allowed us to refine the instrument and reexamine and confirm its reliability and validity. The authors, after refining the instrument, suggest that the revision of SERVQUAL can be conceptualized as follows:

$$
Q_{i}^{*}=\sum_{j-1}^{k}\left(P_{i j}-E_{i j}\right)
$$

Where:

- $Q_{i}^{*}$ is the overall perceived quality of the customer $i$ in the "Revised SERVQUAL";

- $k$ is the number of attributes, 60 in this case;

- $P_{i j}$ is the perception of the result of client $i$ with respect to attribute $j$;

- $E_{i j}^{*}$ is the revised expectation of quality of service of the attribute $j$ for the client $i$.

According to specialists such as [35] [36], the analysis of the quality of service is given by a series of conceptual models and instruments. These are tools that allow the user to measure the quality of the service provided by the providers of different branches of service, and conceptualize quality as the difference between perceptions and expectations. Although the quality has been conceived from the perspective of the client, its measurement cannot be different. For [35], intangible aspects are not easy to quantify, and customer expectations are commonly misinterpreted, which should not be an excuse for not performing the measurement.

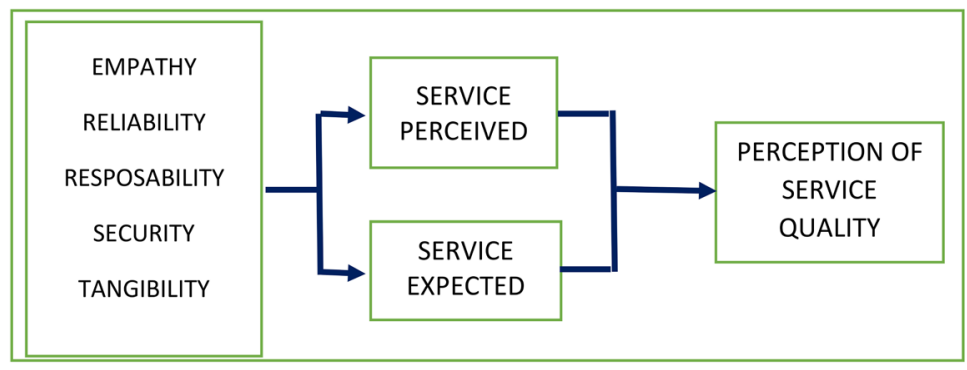

Figure 2. SERVQUAL MODEL. Source: adapted from Zeithaml, Berry and Parasuraman. 
Some of the most widely disseminated service quality measurement models are worked by [4] [36] [37] and [38], are those that manage to estimate the differences between expectations and Perceptions are the model of the five dimensions or criteria, the integral model of the gaps in service quality, the Servqual scale and the Servpref scale. Undoubtedly, one of the most important models for measuring service quality is the Servqual scale, which summarizes the models of differences between perceptions and expectations and that of the five dimensions of service quality or GAPS; This scale is based on questionnaires applied directly to users, incorporating quantitative and qualitative aspects grouped into five dimensions, which gives a total of 22 statements that attempt to collect the expectations of an excellent service and the perceptions on the same dimensions of the services received.

\section{Methodology}

The research is quantitative and qualitative, however, in general, the deductive method and the statistical method for processing and processing data will be used [39]. Using the aforementioned methods, the aim is to achieve the expected results in the proposed objectives [40].

\subsection{Research Techniques}

The research techniques constitute certain more precise and concrete procedures, which will help us in the field work for data collection as well as for the operationalization of the various research indicators. The techniques that will be used in the investigation are:

- Survey Technique. Through this technique, and supported by an instrument (Questionnaire) will be applied to students, teachers and administrative staff on the perceived quality of the different services of the university.

- Statistical Technique. The data obtained in the fieldwork will be quantified, processed and analyzed by means of a Statistical Software SPSS, v. 22 for a higher level of accuracy and reliability of the tests of the different hypotheses formulated in the research project.

The following formula is used to determine the size of the sample (see Table 1):

$$
\frac{N *\left(\alpha_{c} * 0.5\right)^{2}}{1+\left(e^{2} *(N-1)\right)}=
$$

\begin{tabular}{cc}
\hline Calculation of the sample size & \\
\hline Population & $5.0 \%$ \\
Error & 3,808 \\
Size of the population & $95 \%$ \\
Confidence level & $\mathbf{3 4 9}$ \\
Sample size $=$ & \\
\hline
\end{tabular}


Table 1. Research data sheet.

\begin{tabular}{ll}
\hline Population and scope & $\begin{array}{l}N=3,150 \text { students enrolled in the last three semesters of the Professional } \\
\text { Schools in the different Areas: Engineering, Biomedical and Social; } 380 \\
\text { teachers with more than 10 years of service in the UNAP and 278 } \\
\text { administrative personnel with more than 10 years of labor service. }\end{array}$ \\
\hline $\begin{array}{l}\text { Sample size } \\
\text { Sample error }\end{array}$ & $\begin{array}{l}\boldsymbol{n}=349 \\
\text { Population size }\end{array}$ \\
Confidence level & $N=3,808$ \\
Level of dissatisfaction & $p=0.2$ \\
Level of satisfaction & $q=0.5$ \\
Sample design & Simple random sampling
\end{tabular}

Source: Taken the data of the doctoral thesis carried out by Inquilla, J. (2016).

The methodology for the construction of the instrument that will be used to measure the perceived quality of the education service and the empirical verification phase of its reliability and construct validity. In general, the methodology is summarized in two major stages: the structuring, which culminates with the elaboration of the questionnaire for the elaboration of data; and the verification, which aims to show the empirical evidence of the reliability and validity of the proposed scale (see Table 2).

\subsection{Validation and Reliability of the Instrument}

\section{Validity}

For the qualification of the expectations and perception, a numerical scale from 1 to 5 was used, considering 1 the lowest and 5 the highest. The instructions to request both perceptions and expectations read: "Dear user, rate from 1 to 5 the importance you give to each of the following questions related to the care you expect to receive in the different academic and administrative services of the UNA-Puno. Consider 1 as the lowest rating and 5 as the highest rating". For the validation of the new construct, exploratory factor analysis was used for principal components, followed by Varimax rotation. The assumptions of application of the factorial analysis were checked by means of the Kaiser-Meyer-Olkin index (KMO) and the Bartlett sphericity test. A value between 0.5 to 1 was considered appropriate for the KMO index and significant a $p<0.05$ for the Bartlett sphericity test. The reliability of the survey was explored by determining the Cronbach's alpha coefficient, interpreted as good reliability at values $>0.8$ for dimensions of perceptions and $>0.7$ for expectations.

\section{Reliability}

Two questionnaires were applied randomly, both consisting of 63 items, according to the sample obtained. A first questionnaire aimed at obtaining data on the perceptions of students who made use of academic and administrative services at the university; a second questionnaire was used to obtain information. 
Table 2. Proportional distribution of the sample population.

\begin{tabular}{ccccc}
\hline \multirow{2}{*}{ Areas } & \multicolumn{3}{c}{ Distribution of the sample population } & \multirow{2}{*}{ Total } \\
\cline { 2 - 4 } & students & teachers & administrative personnel & \\
\hline Engineering & 95 & 10 & 10 & 115 \\
Biomedical & 95 & 10 & 09 & 114 \\
Social & 95 & 15 & 10 & 120 \\
Total & 285 & 35 & 29 & 349 \\
\hline
\end{tabular}

Source: Taken the data of the doctoral thesis carried out by Inquilla, J. (2016).

The two questionnaires were subjected to tests of validity and reliability, through an analysis of internal consistency, using the Cronbach alpha coefficient, according to Formula 1, for each of the dimensions that were evaluated and for each questionnaire applied. The five dimensions of the quality of service evaluated were: tangible elements (fourteen items), referring to the physical appearance of the infrastructure and facilities, computer equipment, personnel and equipment in workshops and laboratories; Reliability (seventeen items); it is about the ability to offer the promised service in a serious, secure, formal way, free from damages, doubts, risks and insecurities; responsiveness (ten items); considered as the desire and disposition shown by the teaching and administrative staff to help the student and provide them with the best service quickly. User attention and security (six items); considered as courtesy, knowledge, professional competence and the ability to inspire confidence in users. Empathy (eight items); understood as respect and personalized consideration towards the users of the services.

$$
\alpha=\left(\frac{K}{K-1}\right) *\left[1-\left(\frac{\sum_{i}^{2} S}{S_{\text {sum }}^{2}}\right)\right]
$$

where $k$ is the number of items in the test, $S_{i}^{2}$ is the variance of the items (from $1 \ldots i)$ and $S_{\text {sum }}^{2}$ is the variance of the total test. The coefficient measures the reliability of the test according to two terms: the number of items (or length of the test) and the proportion of total variance of the test due to the covariance between its parts (items). This means that the reliability depends on the length of the test and the covariance between its items. Alpha is, therefore, a squared correlation coefficient which, roughly, measures the homogeneity of the questions by averaging all the correlations between all the items to see that, in effect, they resemble each other. The analysis of the data was done using the Statistical Package for Social Sciences software (SPSS v 22.0). Table 3 presents the statistical results obtained from different reliability tests such as the Cronbach Alpha coefficient, for each of the applied questionnaires, the validation of the construct was carried out with the adaptation measure of Kaiser-Meyer-Olkin (KMO), which showed that the variables studied are highly associated and correlated with each other, which allows reducing the number of factors and of course, it is convenient to use the questionnaire for research purposes [41]. 
Table 3. Result of Cronbach's alpha coefficient, for both questionnaires.

\begin{tabular}{lccccc}
\hline Questionnaire & Half & $\begin{array}{c}\text { Standard } \\
\text { deviation }\end{array}$ & Alfa Cronbach & KMO $^{*}$ & $\begin{array}{c}\text { Bartlett's } \\
\text { sphericity test }\end{array}$ \\
\hline Expectations & 4.39 & 0.4884 & 0.754 & 0.841 & 0.000 \\
Perceptions & 2.66 & 0.5502 & 0.849 & 0.709 & 0.000 \\
\hline
\end{tabular}

${ }^{\star}$ Kaiser-Meyer-Olkin construct validation test (KMO Measure). Source: Own elaboration, based on the data processed in the SPSS v. 22.0.

The Bartlett sphericity test showed a significant value $(p<0.000)$, which indicated the association between the variables. The five dimensions of quality studied: tangible, reliability, responsiveness, security and empathy, explained $95.4 \%$ of the variance in five components for the 60 items that integrated the perceptions questionnaires of the academic and administrative services offered by the university. The above indicates, in the results obtained there is a high reliability and feasibility in the used instruments. The values of the Cronbach Alpha coefficient for the perceptions questionnaire are 0.849 for the five dimensions (tangible elements, reliability, responsibility and responsiveness, security and empathy) respectively. The value of the Cronbach Alpha coefficient for each expectation is 0.754 , for the same elements referred to above.

\section{Results and Discussion}

The results found allow sustaining that the perception of students, teachers and administrators is formed from multiple spheres and experiences. Therefore, the quality of service is what the user says from his perception, which is focused at the end of the service process. But the perceived quality is closely related to the adequacy of the attributes of the service to the needs of the user. Consequently, the scale adapted to the Servqual model shows us an Alpha Cronbach of 0.709, this indicates that both the instrument and its attributes are reliable and consistent to measure the quality of academic and administrative service at the University [42]. On the other hand, the results show that students, teachers and administrators associate the quality of the University's service to five dimensions (tangible elements, reliability, user attention and security, response capacity and empathy), its attributes have to do with the facilities and equipment; the academic and teaching quality; academic management, the academic requirement expressed in the student's success in learning; the guidance mechanisms provided to the student in relation to student welfare services; the quality of the research carried out by the teaching staff; the extension actions-social projection and the communication systems used to provide the different services.

In order to establish the exact nature of the relationship [43] estimated the Coefficient of Tau_b of Kendall, with the found values it can be established that there is a high and positive correlation, with a significance of $p=0.000$, in all the dimensions treated, this implies then, that as the attributes or components in the proposed dimensions improve the level of general satisfaction (NSG) on the 
quality of academic and administrative services at the National University of the Altiplano-Puno will improve. When analyzing the values of the coefficients of Tau b of Kendall, by dimensions we have the following detail: As for the attributes or quality components in the dimension "Tangible Elements" the values of $\tau$ indicate that there is a high and positive correlation ( $\tau=0.616$ with a significance of $p=0.000$ ), which means that as the quality attributes in the dimension of tangible elements improve in the same direction, the user's level of general satisfaction improves, that is, there is a relationship of concordance between both variables. On the other hand in the dimension "Reliability" (ability to perform the service in a careful and reliable way) the value of $\tau=0.702$ and $p=$ 0.000 , that is, $70.2 \%$ of the improvement in the level of general satisfaction of the user is addressed with the changes in the attributes or components of the reliability dimension.

Factors or attributes of quality perceived by users of academic and administrative services at the National University of Puno Altiplano.

The factors mentioned above turn out to be conditioning factors to explain the quality of the academic and administrative service at the National University of the Altiplano at a value of $(F=0.000)$, with a coefficient of determination is $\left(R^{2}\right.$ 0.899), which implies that the variation in the quality of service is determined by factors such as: teaching-learning process, quality of teacher training, physical facilities, library, computer centers, laboratories, administrative management and silver communication mechanisms in the study. The value of the Durbin-Watson statistic measures the degree of autocorrelation between the residue corresponding to each observation and the previous one. If its value is close to 2 , then the residuals are uncorrelated, if it approaches 4 , they will be negatively autocorrelated and if their value is close to 0 they will be positively autocorrelated. The case analyzed takes the value 1987, close to 2 which indicates an incorrectness of the waste.

Factor Analysis is a multivariate statistical technique whose main purpose is to synthesize the interrelations observed among a set of variables in a concise and safe way as an aid to the construction of new concepts and theories. To do this, it uses a set of unobservable random variables, which we will call common factors so that all covariances or correlations are explained by these factors and any portion of the variance unexplained by the common factors is assigned to residual error terms that we will call unique factors or specific. Analyze the structure of the interrelations between a large number of variables, not requiring any distinction between dependent and independent variables. Using this information, he calculates a set of latent dimensions, known as "FACTORS", that seek to explain these interrelationships. It is, therefore, a data reduction technique given that if its hypotheses are met, the information contained in the data matrix can be expressed, without much distortion, in a smaller number of dimensions represented by said "FACTORS". A Factor Analysis makes sense if two conditions are met: Parsimony and Interpretability. The model of the Fac- 
torial Analysis is given by $X_{1}, X_{2}, \cdots, X_{p}$ the $p$ variables object of analysis that we will suppose in all the following, that is typified. These variables are measured on $n$ individuals, obtaining the following data matrix:

\begin{tabular}{cc}
\hline Subjects & Variables \\
& $X_{1} X_{2} \ldots X_{p}$ \\
\hline 1 & $X_{11} X_{12} \ldots X_{1 p}$ \\
2 & $X_{21} X_{22} \ldots X_{2 p}$ \\
$\ldots$ & $\ldots$ \\
$n$ & $X_{n 1} X_{n 2} \ldots X_{n p}$ \\
\hline
\end{tabular}

The model of the Factorial Analysis is usually given by the equations:

$$
\begin{gathered}
X_{1}=a_{11} F_{1}+a_{12} F_{2}+\cdots+a_{1 k} F_{k}+u_{1} \\
X_{2}=a_{21} F_{1}+a_{22} F_{2}+\cdots+a_{2 k} F_{k}+u_{2} \\
\vdots \\
X_{p}=a_{p 1} F_{1}+a_{p 2} F_{2}+\cdots+a_{p k} F_{k}+u_{p}
\end{gathered}
$$

where $F_{1}, F_{k}(k \ll p)$ are the common factors and $u_{1}, u_{p}$ the unique or specific factors and the coefficients $\left\{a_{i j} ; i=1, \cdots, p ; j=1, \cdots, k\right\}$ the factorial loads. It is also assumed that the common factors are in turn standardized $\left(E\left(F_{i}\right)=0\right.$, $\left.\operatorname{Var}\left(F_{i}\right)=1\right)$, the specific factors have mean 0 and are uncorrelated $\left(E\left(u_{i}\right)=0\right.$; $\operatorname{Cov}\left(u_{i}, u_{j}\right)=0$ if $\left.i \neq j ; j, i=1, \cdots, p\right)$ and that both types of factors are uncorrelated $\left(\operatorname{Cov}\left(F_{i}, u_{j}\right)=0, \forall i=1, \cdots, k ; j=1, \cdots, p\right)$. If, in addition, the factors are incorrect $\left(\operatorname{Cov}\left(F_{i}, F_{j}\right)=0\right.$ if $\left.i \neq j ; j, i=1, \cdots, k\right)$ we are dealing with a model with orthogonal factors.

$$
x=A f+u \Leftrightarrow X=F A^{\prime}+U
$$

Therefore, the variance of each of the analyzed variables can be broken down into two parts: one, the communality $h_{i}^{2}$ that represents the variance explained by the common factors and another the specificity $\psi_{i}$ that represents the part of the specific variance of each variable. It is for this reason that the factors that are of interest and are amenable to experimental interpretation are the common factors. The unique factors are included in the model given the impossibility of expressing, in general, $p$ variables as a function of a smaller number $\mathrm{k}$ of factors. A possible way of examining the correlation matrix is through Bartlett's sphericity test, which contrasts, under the multivariate normality hypothesis, if the correlation matrix of the observed variables, $\mathrm{R} \rho$, is identity. If a correlation matrix is the identity it means that the intercorrelations between the variables are zero. If the null hypothesis is confirmed $\left(\mathrm{H}_{0}:|\mathrm{R} \rho|=10 \mathrm{R} \rho=\mathrm{I}\right)$ it means that the variables are not intercorrelated.

In Table 4, we have the inverse of the correlation matrix, KMO (Kaiser-Meyer-Olkin) and the Bartlett test. Bartlett's sphericity test is obtained from a transformation of the determinant of the correlation matrix. Where $n$ is the number of individuals in the sample and $\lambda_{j}(j=1, \cdots, p)$ are the eigenvalues of $R$. Under the null hypothesis this statistic is distributed asymptotically according to 
Table 4. KMO and Bartlett's test.

\begin{tabular}{ccc}
\hline Sampling adaptation measure of Kaiser-Meyer-Olkin. &, 709 \\
\hline & Approximate Chi-square & 9178,719 \\
Bartlett's sphericity test & gl & 1770 \\
& Sig. &, 000 \\
\hline
\end{tabular}

Source: own elaboration of the researcher based on the survey.

a distribution $\chi^{2}$ with $p(p-1) / 2$ degrees of freedom. The Barltett Test was used to verify if the correlation matrix is an identity matrix, that is, if all the coefficients of the diagonal are equal to the unit and the diagonal ends equal to 0 . The results of the test they indicate that the value of $\mathrm{Chi}^{2}$ reaches 9178,719 and a degree of significance $p=0.000$, implies that it is not an identity matrix, so it is possible to perform the factorial analysis with the available information.

$\mathrm{KMO}$ is an index that takes values between 0 and 1 and is used to compare the magnitudes of the correlation coefficients observed with the magnitudes of the partial correlation coefficients so that the smaller the value, the higher the value of the partial correlation coefficients $r_{i j}(p)$ and, therefore, less desirable is to perform a Factorial Analysis. Kaise, Meyer and Olkin advise that if $\mathrm{KMO} \geq 0.75$ the idea of performing a factor analysis is good, if $0.75>\mathrm{KMO} \geq 0.5$ the idea is acceptable and if $\mathrm{KMO}<0.5$ is unacceptable. Therefore, for the investigation, it is acceptable to perform the factor analysis because the value of the Kaiser-Meyer-Olkin sample adaptation measure is 0.709 .

\section{Extraction of Factors}

As we have already pointed out, the purpose of Factor Analysis is to determine a reduced number of factors that can represent the original variables. Therefore, once it has been determined that the Factor Analysis is an appropriate technique to analyze the data, the appropriate method for extracting the factors should be selected. There are different methods each with their advantages and disadvantages. For the case of the present study, we have proceeded by the principal components method.

The principal components method consists of estimating the factorial scores by means of the standardized scores of the first principal components and the factorial load matrix by means of the correlations of the original variables with said components. That is, of the 60 starting variables, of which 3 are dichotomous variables that have not been taken into account by the program, so there are 60 variables considered original, of which 15 are factors that are grouped with correlation values very high (see Table 5). On the other hand, the individual and accumulated percentages are shown, the proportion of total variance explained by each of the factors, both for the non-rotated solution and for the rotated value reached is 10.797 over the total variability (60 items) of the total of the sample. Therefore, the fifteen (15) factors included in the analysis are able to explain exactly $69.95 \%$ of the total variability, which can be considered as a very acceptable percentage. 
The commonality is a value obtained in the factorial analysis, for each of the original variables, by adding the squares of the correlations or loads of the retained factors with the variable for which it is calculated and which expresses the proportion of variance of the variable extracted or explained with $\mathrm{m}$ factors, where $m$ is the number of factors retained. If $m$ is equal to the total number of variables, commonality will be equal to 1 . In Table 6 , the factor is interpreted according to the variables most correlated with it. Consequently, the factors that have values above 0.70 are those that explain the variability in greater proportion, so the variables that obtain high values would explain the quality of academic and administrative service in the university.

Table 5. Total variance explained.

\begin{tabular}{|c|c|c|c|c|c|c|c|c|c|}
\hline \multirow{2}{*}{ Component } & \multicolumn{3}{|c|}{ Initial eigenvalues } & \multicolumn{3}{|c|}{$\begin{array}{l}\text { Sums of saturations to the square of } \\
\text { the extraction }\end{array}$} & \multicolumn{3}{|c|}{$\begin{array}{l}\text { Sum of the saturations to the square of } \\
\text { the rotation }\end{array}$} \\
\hline & Total & $\begin{array}{c}\% \text { of } \\
\text { variance }\end{array}$ & $\begin{array}{c}\% \\
\text { accumulated }\end{array}$ & Total & $\begin{array}{c}\% \text { of } \\
\text { variance }\end{array}$ & $\begin{array}{c}\% \\
\text { accumulated }\end{array}$ & Total & $\begin{array}{c}\% \text { de la } \\
\text { variance }\end{array}$ & $\%$ accumulated \\
\hline 1 & 10,797 & 17,995 & 17,995 & 10,797 & 17,995 & 17,995 & 8,228 & 13,714 & 13,714 \\
\hline 2 & 5,603 & 9,338 & 27,334 & 5,603 & 9,338 & 27,334 & 4,677 & 7,794 & 21,508 \\
\hline 3 & 4,027 & 6,711 & 34,045 & 4,027 & 6,711 & 34,045 & 3,871 & 6,451 & 27,959 \\
\hline 4 & 3,053 & 5,089 & 39,134 & 3,053 & 5,089 & 39,134 & 3,217 & 5,361 & 33,321 \\
\hline 5 & 2,777 & 4,628 & 43,762 & 2,777 & 4,628 & 43,762 & 3,077 & 5,128 & 38,449 \\
\hline 6 & 2,346 & 3,910 & 47,672 & 2,346 & 3,910 & 47,672 & 2,712 & 4,521 & 42,969 \\
\hline 7 & 2,252 & 3,753 & 51,425 & 2,252 & 3,753 & 51,425 & 2,282 & 3,803 & 46,773 \\
\hline 8 & 1,790 & 2,983 & 54,408 & 1,790 & 2,983 & 54,408 & 2,203 & 3,671 & 50,444 \\
\hline 9 & 1,705 & 2,841 & 57,249 & 1,705 & 2,841 & 57,249 & 1,886 & 3,143 & 53,587 \\
\hline 10 & 1,486 & 2,477 & 59,726 & 1,486 & 2,477 & 59,726 & 1,765 & 2,942 & 56,529 \\
\hline 11 & 1,477 & 2,461 & 62,187 & 1,477 & 2,461 & 62,187 & 1,678 & 2,797 & 59,326 \\
\hline 12 & 1,290 & 2,149 & 64,336 & 1,290 & 2,149 & 64,336 & 1,653 & 2,754 & 62,080 \\
\hline 13 & 1,238 & 2,063 & 66,400 & 1,238 & 2,063 & 66,400 & 1,602 & 2,669 & 64,750 \\
\hline 14 & 1,126 & 1,877 & 68,277 & 1,126 & 1,877 & 68,277 & 1,573 & 2,622 & 67,371 \\
\hline 15 & 1,006 & 1,676 & 69,954 & 1,006 & 1,676 & 69,954 & 1,549 & 2,582 & 69,954 \\
\hline 16 & ,971 & 1,619 & 71,573 & & & & & & \\
\hline 17 & 948 & 1,579 & 73,152 & & & & & & \\
\hline 18 & 931 & 1,552 & 74,704 & & & & & & \\
\hline 19 & 900 & 1,500 & 76,203 & & & & & & \\
\hline 20 & ,815 & 1,358 & 77,561 & & & & & & \\
\hline 21 & ,781 & 1,301 & 78,862 & & & & & & \\
\hline 22 & ,739 & 1,231 & 80,093 & & & & & & \\
\hline 23 & 696 & 1,161 & 81,254 & & & & & & \\
\hline 24 & 679 & 1,131 & 82,385 & & & & & & \\
\hline
\end{tabular}




\section{Continued}

\begin{tabular}{|c|c|c|c|}
\hline 25 & 662 & 1,104 & 83,489 \\
\hline 26 & 630 & 1,050 & 84,538 \\
\hline 27 & ,593 & ,988 & 85,527 \\
\hline 28 & ,586 & ,977 & 86,504 \\
\hline 29 & ,569 & ,948 & 87,452 \\
\hline 30 & ,547 & ,912 & 88,364 \\
\hline 31 & ,535 & ,891 & 89,255 \\
\hline 32 & ,498 &, 830 & 90,086 \\
\hline 33 & ,476 & ,794 & 90,879 \\
\hline 34 & ,443 & ,739 & 91,618 \\
\hline 35 & ,427 &, 712 & 92,330 \\
\hline 36 & ,405 & ,674 & 93,005 \\
\hline 37 & ,381 & ,635 & 93,639 \\
\hline 38 &, 343 &, 572 & 94,211 \\
\hline 39 & ,340 &, 567 & 94,778 \\
\hline 40 &, 327 &, 546 & 95,323 \\
\hline 41 & ,319 &, 532 & 95,855 \\
\hline 42 & ,271 &, 452 & 96,308 \\
\hline 43 & ,259 &, 431 & 96,739 \\
\hline 44 & ,248 &, 414 & 97,153 \\
\hline 45 & ,222 & ,371 & 97,523 \\
\hline 46 &, 210 & ,351 & 97,874 \\
\hline 47 & 190 &, 317 & 98,191 \\
\hline 48 & ,178 & ,296 & 98,487 \\
\hline 49 &, 173 & ,289 & 98,776 \\
\hline 50 & ,150 &, 251 & 99,027 \\
\hline 51 &, 128 &, 214 & 99,241 \\
\hline 52 &, 116 &, 194 & 99,435 \\
\hline 53 & ,100 &, 167 & 99,603 \\
\hline 54 & ,086 &, 144 & 99,746 \\
\hline 55 &, 061 &, 102 & 99,849 \\
\hline 56 &, 034 &, 057 & 99,905 \\
\hline 57 & ,028 &, 046 & 99,951 \\
\hline 58 & ,021 &, 036 & 99,987 \\
\hline 59 & ,005 &, 009 & 99,995 \\
\hline 60 & ,003 &, 005 & 100,000 \\
\hline
\end{tabular}

Extraction method: Principal Components Analysis. Source: Taken the data of the doctoral thesis carried out by Inquilla, J. (2016). 
Table 6. Analysis of communalities.

Items or variables
The quality of the equipment, material and instruments of the laboratories

are modern

Initial Extraction

The current number of computers in your School or School is adequate

The speed and reliability of the computers in your Faculty is adequate

The Internet speed of the university is adequate

The infrastructure of the classrooms, auditoriums, study spaces and their equipment (multimedia projector, boards, curtains, folders, capacity, lighting 1,000 and ventilation, etc.) of your Faculty or School is adequate

The state of cleanliness and maintenance of the bathrooms, classrooms, auditoriums, study spaces; of your Faculty or School, is adequate

Security services at the university have been efficient

The state of the physical facilities of the library, (infrastructure) are modern and adequate

The physical facilities (infrastructure) of the OTI are adequate for the services offered

The state of the physical facilities where the sports, recreational and cultural activities provided by the unit are carried out is suitable for sports, recreation 1,000 and culture activities

The appearance of the physical facilities (infrastructure) of the different student welfare services (dining, transportation, etc.) is adequate and remains 1,000 clean

The appearance of the physical facilities of the University Dining Room is adequate, and clean

The physical facilities of the services, Dental, psychological and Health Service, are adequate and modern

Perception of the academic requirement in their School or Faculty

The schedule of class schedules is adequate

The services of the virtual campus of the University, is efficient

The professors of the University, in terms of responsibility, mastery of the courses, vocation of service and teaching method is of quality

The management of the directors of the School or Faculty (Dean of the Faculty, Director of the School or Department, Coordinators), is efficient

The management of university managers (Heads of Offices, Vice Chancellors and Rector), is efficient

There is the availability of specialized software in your areas of interest in your Faculty

The University complies with the determined time for the delivery of the requested documents (Certificates, certificates and diplomas)

The service of registration and consultation via the Internet? (subjects, grades, schedules, ratifications and cancellations), are timely and efficient

There is correspondence with the information provided by the system in the library, that is, when you search and order these correspond to the physical $\quad 1,000$ availability of the bibliographic material 


\section{Continued}

The technological update of the library, is timely

There is an adequate availability of bibliographic material (books, software, videos, etc.)

The functionality and usefulness of the databases of the University, is adequate and updated

The teaching method used by teachers in extension and social projection courses is adequate

The current availability of the necessary implements for sports, cultural and recreational activities is the required

The student welfare office satisfactorily fulfills the promised services in the established time and shows sincere interest in solving the problems of the

users

The waiting time (queues) to access the University Dining room service is adequate

The waiting time to make use of the services, Dental, Psychological and Health Service, is adequate

The service provided by officials in the area of certificates, degrees and cash is efficient

He feels satisfied with the services of registration, ratifications and rectifications of subjects

The attention to the public on the part of the officials in the OTI in terms of kindness, communication and knowledge of the work performed, is manifest

The staff of the social services office of the student is attentive, respectful, friendly and also has the training and skills required for the proper execution 1,000 of services

The service provided by the staff of the university canteen is efficient

The service provided by the staff of the Dental Service, Psychological Service and Health Service are timely

The schedules established for the attention to the public in the area of certificates, degrees and cash are opportune for you

The deadlines to cancel the registration are timely

The deadlines for registration processes are adequate

The help and guidance manifested in personalized attention, provided in the Library is adequate

The dates of registration to the program of social projection and extension are opportune

The Vice-Rector for Research responds to your needs, concerns and suggestions

The hours of operation of the different services provided by the social welfare office are timely

The schedules provided by the student welfare office for the provision of its different services are timely

The schedules established by the University Dining Room for the sale of tickets seem appropriate 


\section{Continued}

The schedules established by the health services are adequate to grant appointments and provide the service

The communication mechanisms used by the University to disseminate information of interest to students are adequate

The information provided by the University on conferences, forums, cultural events, scholarships and international agreements, is adequate

The means used to communicate the information of the services provided by the area of certificates and degrees, are convenient

Information about new acquisitions (books, software, videos) from the library

is disseminated through the appropriate means

The means used to communicate the information concerning the services provided by the OTI are convenient

In extension programs, information is easily accessible to the community

The media used by the Office of Social Projection and University Extension to hold academic and cultural events are adequate

The means used to communicate information about the services provided by the social welfare office are adequate

The communication mechanisms for the different services provided by the student welfare office and socio-economic promotion are adequate

The communication mechanisms for the dissemination of information concerning the University Dining Room seem convenient

The communication mechanisms for the dissemination of information concerning the Dental Service, Psychological Service and Health Service are convenient

Extraction method: Principal Components Analysis.

Source: Taken the data of the doctoral thesis carried out by Inquilla, J. (2016).

In Figure 3, the factors (Main Components) with an eigenvalue greater than 1 are 11 (they are the ones that would be selected with the Gutman-Kaiser procedure programmed by default in the SPSS), but from factor 3 there is a clear inflection in the downline, so we can rotate three factors instead of 11 . Three factors will explain less variance than 11, but the structure will be more clear and interpretable. For some authors, and in spite of its imprecision, this is in fact, the preferable procedure to determine the number of factors [44]. Unlike the most usual procedure of Guttman-Kaiser, it is not the absolute values of the variances or eigenvalues but the relative values that are taken into account. With fewer factors, the structure will possibly be clearer although the proportion of variance explained by all the factors decreases. The scree test works well with clear factors and although its subjectivism may be better than the Kayser method. The limitation of this procedure (scree test) is its subjectivism because there is not always a clear turning point in the curve; even so, it is preferable to Kaiser's because it does not seem affected by the number of variables [45]. 


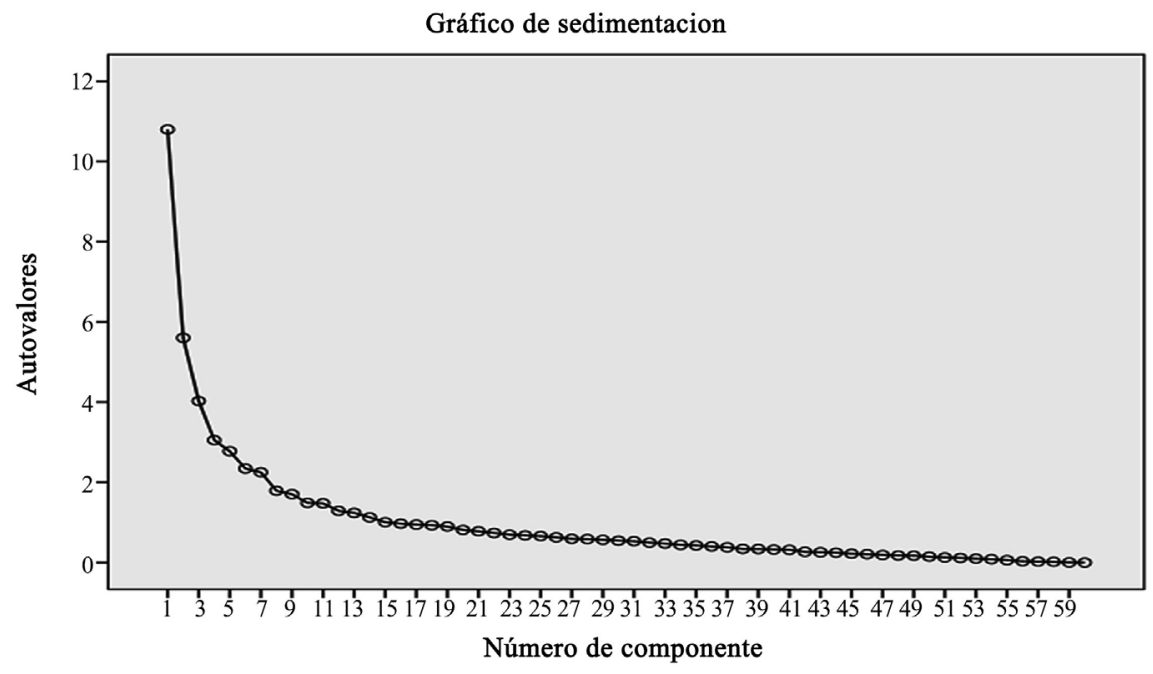

Figure 3. Settling graph.

\section{VARIMAX rotation}

The rotation of Varimax is used, due to the fact that it is a rotation method that minimizes the number of variables with high loads in a factor, thus improving the ability to interpret factors. This method considers that if it is possible to increase the variance of the factorial loads squared of each factor getting some of its factorial loads tend to approach one while others approach zero, what is obtained is a clearer and intelligible belonging of each variable to that factor. The new axes are obtained by maximizing the sum for the $\mathrm{k}$ factors retained from the variances of the factorial loads squared within each factor. To avoid that the variables with greater communalities have more weight in the final solution, Kaiser normalization was carried out, which consists in dividing each factorial load squared by the commonality of the corresponding variable.

The values of the matrix of rotating components, are observed in some components values that have high and low factorial weights, of the fifteen variables selected, in some components have high factorial load (shaded values in bold) indicate that these factors explain that students, teachers and administrative staff of the university, consider more important for the quality of service [46]. Argues that the factors have high saturations and many almost zero in the variables. This means that there are factors with high correlations with a small number of variables and zero correlations in the rest, thus the variance of the factors is redistributed.

\section{$\mathrm{T}$ test for the hypothesis}

To these results were applied the Student's T-test, to establish if there are differences between the users' averages between the received service and the expected service and if the test values differ significantly from a known or hypothesized given value. The test calculates descriptive statistics for the contrast variables together with the $t$ test. By default, the SPSS includes the $95 \%$ confidence interval for the difference between the mean of the contrast variable and 
the hypothesized value of the test. Posing the following statistical hypotheses:

- The null hypothesis (Ho): There is no significant difference in users between the service received and the expected service

- The Alternative Hypothesis (Ha): There is a significant difference in users between the service received and the expected service

The test procedure $t$ for a sample contrasts whether the mean of a single variable differs from a specified state. Thus we can know if a certain sample comes from a population whose true mean is known. This procedure is applied to calculate the significance of the differences obtained by a sample of users of the academic and administrative services of the university, to compare the means of the received service in contrast to the expected service. Table 7 shows, the result obtained shows that the average of the service received by users (students, teachers and administrative staff) is significantly lower than the expected service average, since $p=0.000$, since the average obtained is 3.07 and the average expected 4.40 .

Observing the results we can affirm that discriminant validity exists, the reason why it is ratified that the obtained values are valid in the previous tests. Therefore, the values of $\mathrm{P}$ are less than $0.05(\mathrm{p}=0.000)$, which shows that there are significant differences. That is, both the students, teachers and administrators of the university think or perceive that the academic and administrative services provided by the National University of the Altiplano are lower than expected, therefore, it is of low quality (see Table 8).

Table 7. Statistics for a sample.

\begin{tabular}{ccccc}
\hline Variables & $\mathrm{N}$ & Half & $\begin{array}{c}\text { Typical } \\
\text { deviation }\end{array}$ & $\begin{array}{c}\text { Typical error } \\
\text { of the average }\end{array}$ \\
\hline $\begin{array}{c}\text { General perception } \\
\text { of the service received }\end{array}$ & 349 & 3,07 &, 510 &, 030 \\
$\begin{array}{c}\text { General expectation } \\
\text { of expected service }\end{array}$ & 349 & 4,40 &, 564 &, 033 \\
\hline
\end{tabular}

Source: own elaboration of the researcher based on the surveys

Table 8. Test "t" for a sample.

\begin{tabular}{|c|c|c|c|c|c|c|}
\hline & \multicolumn{6}{|c|}{ Test value $=0$} \\
\hline & \multirow[t]{2}{*}{$t$} & \multirow[t]{2}{*}{$\mathrm{gl}$} & \multirow[t]{2}{*}{$\begin{array}{c}\text { Sig. } \\
\text { (bilateral) }\end{array}$} & \multirow[t]{2}{*}{$\begin{array}{l}\text { Difference } \\
\text { of means }\end{array}$} & \multicolumn{2}{|c|}{$\begin{array}{l}\text { 95\% Confidence } \\
\text { interval for the } \\
\text { difference }\end{array}$} \\
\hline & & & & & lower & higher \\
\hline $\begin{array}{l}\text { General perception } \\
\text { of the service received }\end{array}$ & 101,605 & 348 & ,000 & 3,067 & 3,01 & 3,13 \\
\hline $\begin{array}{l}\text { General expectation } \\
\text { of expected service }\end{array}$ & 131,659 & 348 & ,000 & 4,400 & 4,33 & 4,47 \\
\hline
\end{tabular}

Source: own elaboration of the researcher based on the surveys. 


\section{Multiple Linear Regression Analysis of the hypothesis test}

In order to determine the factors associated with the perceived quality of users about quality service, the following statistical hypothesis has been formulated:

1) Hypothesis:

The conditioning factors of the quality of academic and administrative services perceived by users are related to organizational management, teachers, students, managers, administrative staff, physical infrastructure, financial and IT resources and communication systems. Therefore, there is a direct and significant association between the factors included in the model with the quality perceived by users at the National University of the Puno Altiplano.

Ho: Fc $\leq$ Ft; Factors such as teaching and learning, teacher training, management skills of managers, preparation of administrative staff, physical infrastructure, laboratories and computer centers and communication systems are not conditioning the quality of service perceived by users in the National University of the Puno Altiplano.

Hi: Fc > Ft; Factors such as teaching-learning, teacher training, management skills of managers, preparation of administrative staff, physical infrastructure, laboratories and computer centers and communication systems are conditioning the quality of service perceived by users at the University National of the Puno Altiplano.

Table 9 shows the mentioned factors turn out to be determining factors to explain the quality of the academic and administrative service in the National University of the Altiplano at a value of $(\mathrm{F}=0.000)$; the coefficient of determination is $\left(R^{2} 0.899\right)$, which implies that the variation in the quality of service is determined by the factors mentioned above. With this the null hypothesis is rejected and the alternative hypothesis is accepted, that is, the quality factors of the academic and administrative services in the National University of the Altiplano is conditioned to the factors of the teaching-learning process, quality of teacher training, physical facilities, library, computer centers, laboratories, administrative management and silver communication mechanisms in the studio. The value of the Durbin-Watson statistic measures the degree of autocorrelation between the residue corresponding to each observation and the previous one. If its value is close to 2 , then the residuals are uncorrelated, if it approaches 4 , they will be negatively autocorrelated and if their value is close to 0 they will be positively autocorrelated. In this case, it takes the value 1.987 , close to 2 , which indicates the waste's incorrectness.

Table 9. Summary of the multiple linear regression model.

\begin{tabular}{|c|c|c|c|c|c|c|c|c|c|c|}
\hline \multirow[b]{2}{*}{ Model } & \multirow[b]{2}{*}{$\mathrm{R}$} & \multirow[b]{2}{*}{$\mathrm{R}$ square } & \multirow[b]{2}{*}{$\begin{array}{l}\text { R corrected } \\
\text { square }\end{array}$} & \multirow{2}{*}{$\begin{array}{l}\text { Typical error of } \\
\text { the estimate }\end{array}$} & \multicolumn{5}{|c|}{ Change statistics } & \multirow[b]{2}{*}{ Durbin-Watson } \\
\hline & & & & & $\begin{array}{l}\text { Change in } \mathrm{R} \\
\text { square }\end{array}$ & $\begin{array}{c}\text { Changein } \\
\text { F }\end{array}$ & gl1 & $\mathrm{gl} 2$ & $\begin{array}{l}\text { Sig. Change } \\
\text { in F }\end{array}$ & \\
\hline 1 & $.646^{\mathrm{a}}$ & .899 & .888 & .207 & .899 & 809.206 & 5 & 343 & .000 & 1.987 \\
\hline
\end{tabular}

a. predictive variables: (constant), teaching-learning, teacher training, management skills of managers, preparation of administrative staff, physical infrastructure, laboratories and computer centers, communication systems. b. dependent variable: General User Satisfaction Level. 


\section{Conclusions}

The variation in the quality of service is determined by factors such as teaching-learning process, quality of teacher training, physical facilities, library, computer centers, laboratories, administrative management and communication mechanisms implemented at the National University of the Altiplano. Therefore, the null hypothesis is rejected and the alternative hypothesis is accepted, that is to say, in so far as it improves the attributes (factors) of quality in the provision of academic and administrative services, it will improve the perception of the quality of the service.

The model allows visualizing the factors that intervene in the quality and the relationships that are established between its different factors or components. Therefore, in light of the aforementioned results, it can be synthesized or summarized in three levels or priority factors: First level of factors: they have to do with definition of the mission and institutional vision, as management instruments and that will guide the guidelines of the university and determine the actions of the institution in the future. Second level factors correspond to the organizational context and its main actors that objectify through various processes to achieve the vision and mission raised institutionally, these are teachers, students, managers and administrative staff. This is conditioned by factors such as teaching-learning, teacher training, management skills of managers, preparation of administrative staff, physical infrastructure, laboratories and computer centers and communication systems.

\section{Acknowledgements}

We are pleased to thank the Vice-Rector for Research of the National University of the Altiplano (FEDU), for the support provided, to carry out this research.

To the friends and characters called (Andean sages) of the high Andean communities, we have visited to collect primary information, both in the northern and southern part of the Puno Peru region.

\section{Conflicts of Interest}

The authors declare no conflicts of interest regarding the publication of this paper.

\section{References}

[1] López, F. (1994) La gestión de la calidad en educación. La muralla, Madrid.

[2] González, T. (2000) Evaluación y gestión de la calidad educativa: Un enfoque metodológico. Aljibe, Málaga.

[3] Senlle, A. and Gutierrez, N. (2005) Calidad en los servicios educativos. Edic. Díaz de los santos. España.

[4] Díaz, R. (2015) Factors Affecting the Quality of University Education in Peru.

[5] SINEACE (2012) Educación superior en el Perú: Retos para el aseguramiento de la calidad. Estudio del SINEACE encargado a los especialistas: Gustavo Yamada, Juan 
F. Castro, Mario Rivera. Edic. SINEACE-Lima Perú.

[6] Tejedor, J. (1981) Validez interna y externa en los diseños experimentales. Revista española de pedagogía, 151, 15-40.

[7] Marchesi, A. and Martín, E. (1998) Calidad de la enseñanza en tiempos de cambio. Alianza, Madrid.

[8] Gazi, H., et al. (2000) La calidad en los centros docentes del siglo xxi. Propuestas y experiencias prácticas. La muralla, Madrid.

[9] Bikas, C., et al. (2009) Nuevas dinámicas para la responsabilidad social: Síntesis de los informes GUNI la educación superior en el mundo. 98-104.

[10] Mincer, J. (1974) Schooling, Experience and Earnings. National Bureau of Economic Research, Columbia University Press, New York.

[11] Thurow (1978) Inversión en capital humano. Trillas, México.

[12] Becker, G. (1983) El capital humano. Segunda edición. Alianza editorial, S.A. Madrid, 15-251.

[13] Smith, A. (1776) Investigación de la naturaleza y causas de la riqueza de las naciones.

https://www.marxists.org/espanol/smith_adam/1776/riqueza/smith-tomo1.pdf

[14] Schultz, T. (1960) Capital Formation by Education. The Journal of Political Econo$m y$, 68, 571-583. https://doi.org/10.1086/258393

[15] Domínguez, J. (2010) Evaluación, acreditación, certificación: CONEAU. http://aca-evaluamos.blogspot.com/2010_05_01_archive.html

[16] González, I. (2003) Determinación de los elementos que condicionan la calidad de la universidad: Aplicación práctica de un análisis factorial. Revista electrónica de investigación y evaluación educativa, 9, 83-96. https://www.uv.es/relieve/v9n1/relievev9n1_4.htm

[17] Velasco, L. (2000) La participación de los profesores en la gestión de calidad en educación. EUNSA, Navarra.

[18] Bullón, S. (2007) La satisfacción estudiantil con la calidad educativa de la universidad. Tesis, PUCP, Lima.

[19] Domínguez, C. (1999) Incidencia del desempeño docente y la metodología didáctica en el rendimiento académico de los alumnos de quinto y sexto grado de primaria en dos instituciones de Lima Metropolitana. Tesis para optar el grado académico de Magister en la UNMSM, Lima.

[20] Da Cunha, J. (2002) La evaluación y la calidad de enseñanza. In: Castillo, S., Ed., Compromisos de la evaluación educativa, Prentice Hall, Madrid.

[21] Gento, S. (2002) La evaluación de la satisfacción educativa en un enfoque de calidad institucional. In: Castillo, S., Ed., Compromisos de la evaluación educativa, Prentice Hall, Madrid.

[22] Flores, J. (2003) La satisfacción estudiantil como indicador de la calidad de la educación superior. Documento en línea. http://www.urp.edu.pe/informacion/biblioteca/revistas/articulos.htm

[23] Mejías, A. (2005) Modelo para medir la calidad del servicio en los estudios universitarios de postgrado. Revista universidad, ciencia y tecnología, 10, 81-85.

[24] Oliver, R. (1980) A Cognitive Model of the Antecedents and Consequences of Satisfaction Decisions. Journal of Marketing Research, 17, 460-469. https://doi.org/10.1177/002224378001700405

[25] Lewis, B. and Mitchell, V. (1990) Defining and Measuring the Quality of Customer 
Service. Marketing Intelligence and Planning, 8, 11-17. https://doi.org/10.1108/EUM0000000001086

[26] Parasuraman, et al. (1994) Reassessment of Expectations as a Comparison Standard in Measuring Service Quality: Implications for Further Research. Journal of Marketing, 58, 111-124. https://doi.org/10.1177/002224299405800109

[27] Herzberg, et al. (1957) Job Attitudes: A Review of Research and Opinion, Psychological Services of Pittsburgh.

[28] Druker, P. (1990) El ejecutivo eficaz. Editorial sudamericana, Buenos Aires.

[29] Cottle, W. (1989) El servicio centrado en el cliente. Como lograr que regresen y sigan utilizando su servicio. Díaz de Santos S. A., Madrid.

[30] Parasuraman, et al. (1990) An Empirical Examination of Relationships in an Extended Service Quality Model. Marketing Science Institute Research Program Series, Report No. 90-122.

[31] Schiffman, L. and lazar, L. (2001) Comportamiento del consumidor. Prentice Hall, México.

[32] Muedra, M. (2004) La calidad en la enseñanza actual. Revista Educar, 4, 4-7. http://www.educarm.es/templates/portal/images/ficheros/revistaEducarm/9/revista 8_01.pdf

[33] Reyes, D., et al. (2015) Diagnóstico de la calidad de los servicios de hospedaje en acapulco, guerrero. https://www.redalyc.org/pdf/2631/263139243053.pdf

[34] Feigembaum, V. (1986) Control total de la calidad. Compañía editorial continental, México.

[35] Cantú, H. (2006) Desarrollo de una cultura de calidad. McGraw-Hill, México.

[36] Hoffman, K. and Bateson (2002) Fundamentos de marketing de servicios: Conceptos, estrategias y casos. Internacional Thomson Editores, S.A., México.

[37] Gutierrez (2001) La medición de la calidad: Un instrumento para la gestión del entorno de un destino turístico.

http://www.conocitur.com/.../turismo.../la-calidad-del-destino-tur\%C3\%ADstico--0 $\underline{7031}$

[38] Setó, D. (2005) La relación entre la calidad de servicio y la fidelidad de servicio. Revista europea de dirección y economía de la empresa, 14, 34-47.

[39] Hernández, et al. (2010) Metodología de la investigación. 5th Edition, McGrawHill/Interamericana Editores, México.

[40] Alvira, F. (2004) La encuesta: Una perspectiva general metodológica. Centro de Investigaciones Sociológicas, Madrid.

[41] Cronbach, L. (1951) Coefficient Alpha and the Internal Structure of Test. Psychometrika, 16, 297-334. https://doi.org/10.1007/BF02310555

[42] Inquilla, J. (2016) Modelo Servqual de evaluación de la calidad de los servicios académicos y administrativos de la Universidad Nacional del Altiplano-Puno. (Tesis) Escuela de Posgrado, UNA, Puno.

[43] Inquilla, J., et al. (2017) La calidad educativa y administrativa vista desde dentro: Caso Universidad Nacional del Altiplano-Puno-Perú.

http://www.scielo.org.pe/scielo.php?script=sci_arttext\&pid=s2219-71682017000100 $\underline{001}$

[44] Costello, B. and Osborne, W. (2005) Best Practices in Exploratory Factor Analysis: Four Recommendations for Getting the Most from Your Analysis. Practical Assessment, Research and Evaluation, 10, 1-9. http://pareonline.net/pdf/v10n7.pdf 
[45] Valero, L. (2007) Determining the Number of Factors to Retain in EFA: An Easy-to-Use Computer Program for Carrying out Parallel Analysis. Practical Assessment, Research and Evaluation, 12, 1-11.

https://www.researchgate.net/publication/241436843

[46] Kaiser, H.F. (1958) The Varimax Criterion for Analytic Rotation in Factor Analysis. Psychometrika, 23, 187-200. https://doi.org/10.1007/BF02289233

https://www.psychometricsociety.org/sites/default/files/kaiser_citation_classic_vari $\underline{\text { max.pdf }}$ 